\title{
NARRATIVE GENRES AND THE ADMINISTRATION OF CONSCIOUSNESS: THE CASE OF DAISY GOODWILL'S REBELLION ${ }^{1}$
}

\author{
María Jesús HernáEz LERENA \\ University of La Rioja
}

\begin{abstract}
The Stone Diaries (1993), a novel by Carol Shields, examines the strategies characters use to render their selves accountable: they turn life into an ensemble made up of historical, scientific, novelistic or biographical discourse. In contrast, Daisy Goodwill, who is the subject-matter of this fictional autobiography, remains close to the epistemology of the short story, whose potential has been described by critics as a challenge to knowledge or synthesis (Cortázar 1973; Bayley 1988; Leitch 1989, May 1994; Trussler 1996). There seems to be agreement that the only condition of coherence necessary for the short story is a pointing to the evasion of meaning in life, also that the genre allies itself to the way in which the past is attached to our memory (Kosinski 1978; Hallet 1998; Lohafer 1998; Wolff 2000). This essay will analyze the implications of its protagonist's stance with a view to pinning down some of the ideological grounds of the novel and of the short story in their approach to the question of identity.
\end{abstract}

$[\mathrm{H}]$ ow are we to understand the project of telling a life story where it must be organized in terms of what is anomalous, difficult, and resistant to narration? (Gilmore 2001: 33)

This article deals with the question of how we articulate our consciousness by focusing on the proposals of two major narrative genres: the novel and the short

1. The research carried out for the writing of this paper has been financed by the Spanish Ministry of Education ("HUM2006-09288) through the project "Penelope's Embroidery: Literary Tradition, Cultural Identities, and Theoretical Discourses in the Anglo-Canadian Fiction of the Late 20th Century". 
story. One of society's demands upon the individual is precisely self-articulation, the creation of an identity of one's own made manifest by an exercise in verbalization. This task is performed through the adscription of meaning to a sequence of incidents and emotions, that is, through the making of a story. Thus, the psychological structures we use to make sense of ourselves seem to put us unavoidably in a narrative dimension; we read ourselves as characters in a story. ${ }^{2}$ The interplay between storyness and personal biographical composition will be the object of this study.

The finality of a life story is knowledge, or at least, intelligibility, a goal reached thanks to certain formulaic beliefs which allow us to connect events within a sequential pattern of progress which - we imagine - moves us towards the future and diminishes the chaos of existence. We like to believe that experience leads to maturation, that the cause-effect binomial organizes our life and explains the conditions of our present situation, that the passing of time brings about learning (intellectual, emotional, ethical). These assumptions, which no degree of postmodernism will be ever able to uproot, act like joints which help interpret the succession of occurrences in one's life - or in a character's life - as the dramatization of the efforts towards self-understanding, a path sanctified with the aura of redemption. These ethical dynamics of narrative is grounded in the religious precedent of sacrifice followed by reward. It is the metaphor of life as a river or as a journey which starts as blankness or as confusion and achieves its climax in an adjustment of perception (an awareness of wrongness) or in a more satisfactory appreciation of the relationship between a person and his/her world. However, not all narrative genres share the same joints or the same sense of finality. Indeed, the short story has been often defined as contrary to the ingrained idea that stories have to make transitions plausible or intelligible. In its search for truth in the clash of experiences which do not cohere, the short story shows ample disregard for other genres such as the novel or the biography, which often equate reality with a slow display of psychological interiors. Aspirations toward knowledge also fare differently in both genres: whereas the short story is said to have constituted itself in its challenge to knowledge and has a penchant for situations that cannot be rationalized (Leitch 1989: 133; Trussler 1996: 560), the novel has historically sought the "expropriation" of life's mystery (May 1994: 135); it evidences a will to dissect the machinery of connections at play in an individual's existence. Our culture has made us mainly inheritors to the legacy of the novel, a form of discourse which reveals life as an ongoing pattern connecting the past to the future. The novel's

2. See Rose (1997: 237). 
appearance as a life-long companion is firmly rooted in a sense of biographical time: its embodiment of learned ideas of self as history makes it possible to envision life as a path that is psychologically self-sustaining. ${ }^{3}$

Alien to this "ethos of connection", the short story is often seen as an unfinished narrative product: it traces the lack of "jointedness" of experience, it finds and revolves around a situation which makes life's reassuring continuity recede from view. It dismantles the notion of the "sequential self" because it negates contiguity; always ecstatically pointing at a mystery or a paradox, it seems to propose a category of person structured nonsensically. By prioritizing the disarming power of a hypnotic moment, a person's life is shown as strayed from a set course.

Much worthy theory and criticism has been produced about the differences between the novel and the short story in terms of epistemology, textual tactics, narrative structure, and reader-response. However, the capacity of these two genres to create different models of identity still remains somehow unexamined. Both narrative forms shape and make available certain patterns we use to attach an identity to ourselves. On a different front, but on one that we can use as a suitable background, Anis Bawarshi (2003: 86) has regarded non-literary genres as sites of "subject formation", as constitutive of identities. According to him, certain genres are associated with typified subjectivities, that is why he studied generic habitats outside the strict literary environment in order to show how a certain rhetoric makes us think of ourselves. ${ }^{4}$ Genres are not thought of as descriptive or classificatory, but as generators of communicative goals by way of its ideological and discursive conventions.

3. Bakhtin (1991: 242, 253, 269) defined biographical time as thread-time, as a path man traverses, as a journey or transition that modifies people. Biographical time is supported by the notion that life affects us as a sequence, as a whole and indivisible mass. When dealing with the advent of the novel, Roland Barthes (1988: 145-146) claimed that our society has developed this reassuring notion of time to "unite as rapidly as possible a cause and an end". It is a "security system", "the ideal instrument for every construction of the world" because it paves the way for an intelligible narrative. In this construction, reality is not mysterious or absurd: "The Novel is a Death; it transforms life into destiny, a memory into a useful act, duration into an orientated meaningful time" (150). According to Barthes, time in the novel is tamed in order that our society can universalise its views of history and life. For other explanations of this institutionalised version of time, see Kermode (1968: 7-8), Raible (1988: 308) or Alverson (1994: 97).

4. An example is "The Patient Medical History Form" (2003: 83) (PMHF) a form that American patients have to complete prior to their seeing a doctor. Here, the individual learns to think of himself as a patient and to absorb a series of beliefs, social positions, and linguistic terms which will rule his future interaction with the doctor. Other conceptual habitats are found in the relationship between professors and students at university, where different kind of written assignments perform regulative, managerial or creative functions (85). 
Although Barwarshi's inventory of genres does not include the more embracing literary generic frameworks this essay examines, nonetheless his perspective legitimizes the approach undertaken here: genres establish the rhetorical conditions that help to organize our desires and subjectivities and create assumptions as to what is knowable (or doable). Subjectivity will be looked for in the negotiation between a certain kind of generic pressure and a set of internal structures which may transgress generic demands.

Thus, this will be our working hypothesis: different narrative genres give us different views of the human power to understand reality and they generate schemas within which we can understand ourselves. Although a great variety of subgenres exist, my focus will be mainly on the novel and the short story because their opposed views on the issue of the narrativity of existence channel two basic impulses which may be present, in different degrees, in any fictional work. These two genres represent two different commitments to story understood as an explanatory structure. As a starting point, we claim that the strategies we use to narrate our past to others and to ourselves can comply with two conventions: we may assume that life has been experienced in a continuum, with stages made up of events, emotions, and thoughts which can be labeled and which enable us to explain subsequent occurrences (the novel does this kind of job for us). Or we may feel that our past contains certain moments in which we remember ourselves under the effect of some compelling sensory or psychological force that is unconnected either temporally or causally with the rest of our existence. The short story undertakes this second task.

Can we say that this approach constitutes an either/or existential motivation? Do we consider one form of remembrance more appropriate than the other? Does the short story's disbelief in coherent contiguity undermine the validity of the novelistic experiential flow? Or is the moral weight of an ideal well-articulated novel more fulfilling than the fleeting, less vertebrate sense of self that the short story promotes?

In Carol Shields' The Stone Diaries (1993) we find a novel in which these two potentialities for self-contemplation are at odds. This fictional autobiography cannot be properly realized as such because its protagonist, Daisy Goodwill, is unable to verbalize her life according to a novelistic pattern of intelligibility. Daisy is both narrator and character, but both the narrator and character within herself fail in performing their roles: Daisy the narrator rarely has a privileged access to her own internal affairs, and Daisy the character refuses to be pinned down within any pre-established arrangement of vital stages. This novel is not the first case of an autobiography where the main character is absent; its peculiarity lies in the fact 
that this absenteeism of the self is due to the conflict of two forces at play: the desire to narrate versus the conviction of life's lack of narrativity. Let's look at this battleground more closely.

Almost at the end of her life Daisy Goodwill asks herself:

What is the story of a life? A chronicle of fact or a skillfully wrought impression? The bringing together of what she fears? Or the adding up of what has been offhandedly revealed, those tiny allotted increments of knowledge? She needs a quiet place in which to think about his immensity. And she needs someone - anyone - to listen. (340)

In this passage Daisy brings to the foreground our need to accommodate our lives to certain versions of narrative, and although the novel is not just a chronicle of fact and the short story is not only a skillfully wrought impression, Daisy's life, having been patterned by the author as an autobiography of forward movement, leaves her "throttled, erased from the record of her own existence" (76). Daisy remains absent for the most part of a narrative that has chaptered her life within the phases of birth, childhood, marriage, love, motherhood, work, sorrow, illness, decline, and death. We are offered a gigantic web of stories, also photographs, documents and letters that survey the world she lived in and the persons she interacted with, but she remains anonymous, out of sight. We only know that, in sharp contrast to the other characters, Daisy felt the chronic disease of not being able to grasp her experiences as "beads on a string" (340). Her identity was emptied out, annihilated, precisely because she was unable to turn her own life into a novel. We apprehend her as an unknowable and isolated being, submerged under heavy layers of a narrative that marches on and around her, full of characters busy with the business of constructing their own life stories and providing Daisy with their own interpretations.

Daisy is aware that she has been crowded out of her own life by history and narrative, that her experience lacks continuity, progression, and connectivity. These novelistic and biographical arrangements operate like a conspiracy to defraud her of her own life; she can only get hold of herself at certain moments when her mind regurgitates a few sensations of her past that she can relish anew, but these are deprived of any communicative pact, unhinged from what came before or after. She does not conceive of herself as a "psychology in time", a definition that would suit novelistic standards, but as an intermittent soul, unable to find the joints that would connect her to a universal tissue of storyness. However, as a compensatory gift, she can temporarily arrest the course of time, "the curse of continuity" (309), as she thinks about it, in order to be possessed by images which press on her with the 
solidity of the present moment. While in hospital, already in her eighties, Daisy experiences an earlier self coming back to her:

She is seven years old, standing in her Aunt Clarentine's garden, stooping over the snapdragons, pinching them with her fingers so that their mouths open and close. They possess teeth and tiny tongues. Do other people know about this? "Daisy" she hears. She's being called in to supper. Aunt Clarentine's promised to make pancakes tonight. All this: the thought of the pancakes, the hot bite of chives, the hidden throats of flowers, the sound of her own name -she is suddenly dizzy with the press of sensation, afraid that she will die of it. [...]

The brown leaves had been raked into a pile ready to burn. [...] She let herself fall backward, her arms straight out, trustingly, and at once the complications of branches, fences, sheds and houses, so dense and tangled together, burst with a cartoon pop into the spare singularity of sky, the primary abruptness of blue. That's all there was. Herself suspended in a glass sphere. You could go back and back to that true and steadfast picture, hold it in your head for the rest of your life. (338-339)

She can only contemplate herself suspended, the weight of her memories distributed unevenly, as "sparkling subversions" (337). But only very rarely does the reader become a witness to these triumphant outbursts of individuality: Daisy's thoughts and words remain unspoken; instead, the narrator explains that she was only aware of the inauthenticity of her own life, never managing to articulate it in order to offer it to others. The narrator herself and other characters keep telling us that "Daisy Goodwill's perspective is off" (148), that "she was forever going after some stray little thought with a needle and thread" (356), a woman to be pitied, unable to manage a well-run identity. She is aware that her lack of anchorage to life comes as a result of her inability to abide by the connecting system of dispositions available in biographical discourse and, in this novel, the apparent implication is that her impotence in weaving her life's landmarks kept Daisy forever diminished, insubstantial, forever on the margins of her own life.

Thus The Stone Diaries partly revolves around this question: does the inability to construct a continuing plot for one's life inevitably lead to lack of identity? Is the "ethos of connection" so typically represented by the novel the only pattern of intelligibility possible?

We cannot help relating Daisy's stance with the epistemology of the short story genre not only because of her choice of resisting sequentiality and of inhabiting a realm of suspended temporality - allied, as some critics have noted, to our own processes of personal remembrance (Wolff 2000: xi-xii) -, and also 
because her awareness of where reality is and how it is accessible to us offers an alternative proposal to the novel-oriented habits of the other characters and of Daisy herself as a narrator of her own life.

Many critics and short story writers have spelled out the epistemology of the short story as a genre which intrinsically possesses a certain attitude to knowledge, this attitude consisting of putting it aside temporarily; they insist on the short story's irreducible component of wonder and mystery, its reliance on paradox, a figure which cannot reconcile different truths, or on the puzzle, since the reader cannot provide the story with a plot and, not least, its dependence on the potentiality of images that cannot be integrated into a larger consensual reality (Hanson 1989: 25). Short stories insist that the nature of meaning is private, not shared or fraternal. Bayley (1988: 126), for example, affirmed that the short story commits itself to the literary as enigma, pointing to a mystery that lies outside any discursive answer; May (1994: 133-135) claimed that the short story, unlike the novel's original impulse to understand the world, addresses those experiences that cannot be dissected and analyzed; Leitch (1989: 133) defined the short story not as a form of knowledge, but as "a means of unknowing"; Trussler (1996: 560) explains that the short story is grounded on a hermeneutic crisis, on the failure or the refusal to explain the relationship between passing time and event. From different perspectives, criticism on the short story points out that short stories contain "ghost" or secret plots (Rohrberger 1998: 203), that the relevant experiences in a short story are muffled (Hannah 1998: 208) or that the reader experiences an incongruity in existential experience as a slap in the face. It has also been noted that the short story has no responsibility other than showing life fissures (Rueda 1992: 29): a mere disturbance in a previously unmolested course of a life can satisfy us imaginatively as the plot of a short story. It is a step aside, not forward. The short story exploits our lack of acquaintance with its fictitious worlds and its transitions. All these assimilations of the genre stress the fact that what is real for the short story writer is that which evades understanding or coherent articulation, in other words, that which cannot be narrated.

In view of this orientation of the short story towards the incongruous, the isolated, the unfinished, the disturbing, the unattainable, the perplexing, it may be perhaps pertinent to ask why some writers, readers, and critics are addicted to a literary form that apparently denies them the comforts of narrative per se, with its chaining of events, its sustained incursions into the character's lives and minds, its wrapping-up sensation that we are accompanying characters in a journey from which some knowledge is to be gained, its reassurance that we participate fully in a world spread out there for us. Why should we forget about the whole mechanism of life to entertain ourselves with the enigmatic quality of a spare part? 
(I mean by "spare part" a piece of a larger mechanism that at any precise moment does not serve the purpose of keeping that mechanism going).

Ulrich, the protagonist of Robert Musil's novel The Man Without Qualities (1952) expresses this apparent quality of "senselessness" of the short story when describing what his lover thought about an evening they had spent together:

Her friend regarded such an evening as a ripped-out page, alive with all sorts of suggestions and ideas but mummified, like everything torn from its context, full of the tyranny of that eternally fixed stance that accounts for the uncanny fascination of tableaux vivants, as though life had suddenly been given a sleeping pill and was now standing there stiff, full of inner meaning, sharply outlined, and yet, in sum, making absolutely no sense at all. (20)

This passage illustrates Daisy's marginalized model of self-knowledge in The Stone Diaries and points at the risks of refusing to comply with the demands of a narrative articulation, which provides characters with context, motive, and progression. Are we truer to reality when we look at it without a larger explanatory context? One of the short story writer's abilities is precisely to move us by rendering useless our habitual mechanisms to make reality intelligible. In The Man Without Qualities, as in The Stone Diaries, we also find the case of a novel whose character is unable to cope with narrative, however intensely he is aware of the advantages to be gained from a novelistic organization of his own life: "Lucky the man who can say 'when,' 'before' and 'after'” Ulrich says,

[t]his is the trick the novel artificially turns to account. Whether the wanderer is riding in pouring rain or crunching through snow and ice at ten below zero, the reader feels a cozy glow [...] because it has the look of necessity, and the impression that their life has a 'course' is somehow their refuge from chaos. (708-709)

What interests me about Ulrich's manifestation is mainly his conviction about the way we should relate to ourselves if we wish to survive pointlessness and the overwhelming multiplicity of existence. He associates a novelistic notion of ourselves with a survival mode of narrative, but if this were the case, would the short story's approach to knowledge mentioned earlier imply the impossibility of a satisfactory and sustained sense of self?

Contemporary critics often call our attention to the fact that story is an inescapable feature of human life: we assimilate reality and we make sense of ourselves through narrative (Taylor 1996: 51). The claims are that identity demands verbalization, more specifically, narrativization (Fernández Prieto 1994: 124-125), that there is no identity previous to the act of narration. In order to achieve a sense 
of the self, we have to become a narrator and construct a plot in which we fashion some of our pasts as characters. Giddens (1991: 54) asserts that we are not to find a person's identity in behavior, or in the other's reactions, but in his or her ability to keep a particular narrative going. The self is no longer a list of qualities, but a narrator in search of coherence. When analyzing confessional narrative Forster (1987: 10) remarks that "[n]o matter how one's experiences may be present in memory, the events of these narratives are understandable only when they are transformed into objects of consciousness, into histories rather than sensations", an argument which clarifies Daisy's dilemma and her incapability to pin down her life within a contextualized historicity.

In The Stone Diaries we can discern these two conflicting attitudes to selfknowledge once we realize that Daisy the narrator and Daisy the character represent two different attitudes to the narrativity of the self: Daisy the narrator tries to impose a novelistic plan on her life, she uses narrative to try to communicate how an individual was encased in the world, but her responsibility to transmit how a subjectivity was shaped by space and time is thwarted by Daisy's rebellion as a character, who feels that this trajectory is how the narrator within her and the other characters try to assimilate her, but intuits its inadequacy in relation to herself. It would be interesting to mention here that Hillis Miller (1979: 14-15) considered the novel to "represent human experience as standing outside itself" and, in the same connection, Jerzy Kosinski (1978: 160) defined our individual consciousness as composed of very short incidents; according to him the plot, a sense of destiny, is provided for us only by outsiders, "by family tradition, by society, by a political party, or by our own indoctrinated imagination" [...] "Maybe that is why we believe that everyone has one novel in him: his own empirical existence - if he can extract his self from it".

Daisy's instinct goes against this lifetime's training and understands the effects of time as a shipwreck - only a few objects will come to the surface eventually, and when they come, she acknowledges their lack of anchorage to the plausible movement of the world. The chapter entitled "Childhood" is brought to a close when Daisy's father, a well-known orator, decides he owes Daisy the story of his life after so many years of absence. Then, on the train from Manitoba to Indiana, he delivers the longest speech of his life, which lasted two days. While this chaptered account is in progress, Daisy is storing the materials she will use later in life for purposes other than purely narrative:

The two of them were drinking lemonade from tall tumblers.

Who made this lemonade? Someone must have squeezed the lemons and stirred in cups of sugar and added chipped ice, but Daisy can't think who this person 
might have been. Nevertheless her fingers will always remember the feel of those tumblers, the pale raised bands on thin pink glass, but it is the sun she will chiefly remember - how yellow like corn meal it was, sifting through the fine summer curtains and filling up the whole room. These, at least, were the things she might believe in: the print of sunlight on her bare arm. The cold sweet drink sliding down her throat. The buttons on her father's shirt, glittering there like a trail of tears.

Her knees formed little hills, poking up through the yellow cloth. Her father's words came to her like a blizzard of dots.

On that day she liked the world. (77-78)

Her father's mainstream narrative blinds Daisy but she stores in her memory the pieces that make up an autonomous moment of her childhood, "highly telescoped", as Jerzy Kosinski would have said. ${ }^{5}$ Daisy imagines all the other "men and women in the world, who wake up early in their separate beds, greedy for the substance of their own lives" (283), and are obliged every day to edit their memories in a "then-and-then" narrative, but why can't she do it herself?

According to Charles Taylor (1996: 18) in Sources of the Self, not to use this framework for one's life is to fall into a life which is spiritually senseless. He rejects the value of the immediate experience or the sudden rupture by explaining that our notion of ourselves only comes through the story of how we have become, the unfolding of "how we have travelled to get here" (48). The self cannot be punctual or instantaneous. Self-understanding necessarily has temporal depth, sense of direction, and incorporates narrative. If we think of ourselves as different persons or we fail to meet the full challenge of making sense of our lives we condemn our chances for a meaningful life. So without these reasonings in transitions, Daisy's ethics of inarticulacy would be deprived of any validity, it would almost be an offence. Yet, why do we feel that yes, she does exist outside the gigantic mechanism of causes and effects, that she is a latent but real presence, even if she did not endorse the memory of herself as a continuous individual with a biography?

In the essay "Assembling the Modern Self", Nikolas Rose (1997: 224) poses a very interesting idea which can be related to the above-mentioned conception of

5. That Carol Shields has filled her novel with allusions to some poems of Emily Dickinson such as "A Slant of Summer Light", "I Like a Look of Agony" or "I'm Nobody! Who Are You?" emphasizes the engagement of this novel with the complex relationship between narrativity and existence. In these poems Dickinson claimed the truth of certain perceptions which religious or social systems left unaccounted for, and she expresses the grind of having to assert one's identity to others continually under the risk of banishment. 
the self as narrator. He explains that the enormous influence of the language and systems of the sciences of the self: psychology, psychiatry, psychotherapy, etc., has contributed to making experience independent of individuals: once our experiences have been classified and described and gone on stage, so to speak, they come back with new authority, with their phases, types of explanation, and specific lexicon. To a very great extent, this is what happens in The Stone Diaries, where all those characters who knew Daisy well proclaim themselves "experts of experience" and get entertained in very long theses with similar grammars of causes and effects, their groundings in family history, their diagrams of interior forces and feelings and reactions - the accounting for Daisy's present in terms of her past. What Nikolas Rose (243) calls the "psy" language has made us inhabit particular styles of remembering ourselves and of explaining other people: "Freud not only devised a language of description, he invented a novel schema for the direction of souls".

Rose draws our attention to the fact that this kind of narrative has a therapeutic design: if we engage with the self and try to render it into speech that is because we want to take control of our lives "within an ethics of empowerment" (244). So we want to make our past narratable in order to make life more practicable to our purposes. Our voice of introspection is a doctor with a cure in mind, that of meaning and finality. Previously we defined the self as a narrator, but this narrator is indeed a narrator not basically because narrative is our only form of understanding, but because narrative gives us the comfort of understanding, because narrative, looked at from this perspective, establishes a healing link between ourselves and experience.

Charles May (1993: 376; 1994: 133-138) has dug into psychology and philosophy in order to show that the novel depends greatly on a survival mode of narrative. In contrast, the short story seems to be engaged in disrupting those narrative tools which make us intelligible to ourselves in relation to others. I do believe we respond instinctively to the short story on these terms: from a novel, however experimental it may be, we always expect to get engaged in a trajectory which submerges us into the mechanics of a world that moves both by external impositions and the motivations of its participants and that, although we may also become witnesses to this ensemble in the short story, in a short story we are eager to find that piece that would refuse to be assimilated by this therapeutic monopoly of understanding. We find that our sense of direction is displaced by a single point of urgency, the impression that the raw material of this genre, its storyness, is used for the purpose of making us feel how unfounded progress is, and how we are forever at the beginning. Perhaps that is why a critic said that to think about the short story is to 
imagine "an impossible larva" (Balza 1995: 65), as if the short story itself would try to undo the medium which fleshes it. We do not expect a narrative which tries to make sense of the world, but a narrative whose only condition of coherence is to make us sense the world, where things are rather than come into being. ${ }^{6}$

The character Daisy in The Stone Diaries chooses a particular style of remembering herself, using Rose's expression, in dissonance with narrative as understanding and self-mastery. We observe this in her account of herself as experiencing lapses untied to time, her dependence on a world of sense rather than thought, her will not to possess but to be possessed by certain manifestations of life. This unnarratable version of the self, based on the hypnotic quality of a situation, "as if the world had been given a sleeping pill" quoting Robert Musil's words, chooses to look, not to explain. Her own name, as she realizes late in life, means "Day's Eye", giving the "eye", the sense of sight, the same status as "I" the self. She makes private monuments of the things her mind absorbs without turning them to currency.

This way, Daisy's inner voice, silenced by so many stories, will surface now and then in the novel. We understand that her existence was real, only that it could not be adjusted to predominant models of novelistic identity. The other characters think that there is absence and emptiness in Daisy - considered as an "identity site" -, but in fact there is only a lack of conventional articulation. Sometimes Daisy is tempted by the lure of narrative and imagines what her life would be like should she apply a generic mould to it:

She understood that if she was going to hold on to her life at all, she would have to rescue it by a primary act of imagination, supplementing, modifying, summoning up the necessary connections, conjuring the pastoral or heroic or whatever, even dreaming a limestone tower into existence, getting the details wrong occasionally, exaggerating or lying outright, inventing letters or conversations of impossible gentility, or casting conjecture in a pretty light. (76-78)

The act of making a narrative, that is, of rescuing life from randomness, is seen as having a remedial quality and it promises healing. But in spite of her Good Will, Daisy is never totally persuaded to take the bait: the available genres are too artificial; she does not feel part of a collective enterprise. The kind of mental activity she wishes to develop is perceptual rather than cognitive, she wants to hold on to

6. The short story does not address the question "who am I and how did I become who I am?", instead it mocks that question because it eludes a sense of biographical time, as if this kind of time did not fit well into the experience of ourselves. The short story can be defined as a "stranded narrative", since it exposes a condition grounded in a hermeneutic crisis. 
experience prior to story formulation and leave each object or person that fell under her attention undisturbed. Her acute feeling of being swamped by "the great story" (125) is, however, relieved by the irruption of the irrational:

And yet, within her anxiety, secured there like a gemstone, she carries the cool and curious power of occasionally being able to see the world vividly. Clarity bursts upon her, a spray of little stars [...] The narrative maze opens and permits her to pass through [...] Tonight Mrs. Flett is even touched by a filament of sensation linking her to her dead mother, Mercy Stone Goodwill; this moment to be sure is brief and lightly drawn, no more than an impression of breath or gesture or tint of light which has no assigned place in memory, and which, curiously, suddenly, reverses itself to reveal a flash of distortion -the notion that Mrs. Flett has given birth to her mother, and not the other way around. (190-191)

Daisy's adoptive aunt, Clarentine Flett, the other female character who does not possess the comforting gift of narration, also experiences uprooting moments which disconcert her as well as provide her with another life that makes her stand apart from any coherent history. Her understanding of life implicitly rejects notions of progress and continuance and vindicates the way in which the past is attached to our memory, "glued to it" as little bits of residue; a small part will grow out of proportion, it will displace life's other tides:

These segments of time are untied to any other time she recognizes. It happens more and more frequently, these collapsed hours, almost every day since the summer weather came on. She wakes up fresh enough, but as the hands of the clock move forward she feels a force beckoning, the teasing of seduction of ease and secrecy, and then, with the next breath, she's lost the battle. Whatever it is that encloses her is made up of tenderness. It rises around her like a cloud of scent. There's no face or voice to it, only a soft, steady, pervasive fragrance, a kind of rapturous wave that enters her throat, then moves downward through her body, springing tightness to her female parts and the muscles of her softened thighs. The silence is perfect, and yet a torment - that God is not interested in her lapses. He has not spoken out to her in any way, has not given a sign [...] It is frightening, and also exhilarating, her ability to deceive those around her; this is something new, her lost hours, her vivid dreams and shreds of language, as though she'd been given two lives instead of one, the alternate life cloaked in secret. (11-12; my emphases)

It is significant that those moments in which Clarentine seems to have an intensified conscience of herself are not described as thoughts, but as physical sensations thoroughly severed from language, rational explanation, or shared plot. Like Daisy, she is more true to herself when she does not have to infuse the world 
with narrative and she can get lost in the rapture of her senses. These unhinged moments are not only invisible to the others, but are also thought to be unwanted and even shameful: intervals to be discarded by the Supreme Authority as unworthy. However, the notion of hollowness transmitted in the previous excerpt effectively functions as a proposal which negates the linear order, creating the outside in time.

Serrano (1995: 42) claims that life is unfinished or dark if there are not narrations about it. Daisy and Clarentine seem to have appropriated their past inadequately since they experience it as an accumulation of disconnected images, which would provoke unhappiness and desperation, according to Serrano. A mere list of perceptions replaces a chain in Daisy's mind: a relative's voice, light entering a room, the feel of a heap of dry leaves. Are these things insufficient to create the plot of a life?

The Stone Diaries revolves around two poles of significance, on the one hand the stone, the public monument, symbol of duration and continuity, associated with the male protagonists of the novel: the orator and historian, the scientist, the businessman, who construct their lives on the assurance of progression and achievement. On the other hand we have the diary, symbol of the silenced, the secret, without scenic pact, a narrative that does not have a socializing function, but it is devoted to the space man knows is occupying alone, as Elizabeth Bowen (1994: 262) said about the short story.

In the case of Daisy Goodwill, the impossibility of connection does not necessarily entail an emotional or intellectual wreckage, as Taylor and others have claimed (Serrano 1995: 42). Daisy's grasp of time is similar to that of Borges (1967: 148) when he said in a poem: "What of successive time if in it/there was a plenitude, an ecstasy, an afternoon" (my translation) showing again, as Bachelard (1969: 8) had claimed, that all we know is fixations in space, that "we are never real historians but always near poets". For Daisy, who has been given a short-story soul, this apparently anti-therapeutic use of her past served to occasionally fill her life with a few tokens of joy and solidity. In any case, she remains adamant, not allowing the narrator within herself to novelize her. She shows that life strikes us as short story although we have been trained to think of it as a novel.

7. Rita Kleinhart, another heroine absent in her biography, The Hornbooks of Rita K by Robert Kroetsch, shows a similar appreciation of life when she says that some colorful flowers which appear every year on a dry slope give her reason to live: "A patch of scarlet mallow appears each spring in the / grasses on the edge of the coulee directly in front of my / house. That little patch of orange-red blossoms, emerging/on a dry, south-facing slope, is one of my reasons for living" (36). 
The Stone Diaries strikingly embodies and rethinks the issue of how we pursue biographical meaning by bringing to the foreground the interaction between novelistic demands and the patterns we use to attach an identity to ourselves. Although the genre of the novel has never been subservient, not even in the eighteenth century, to the belief in an unprejudiced access to an objective (or subjective) reality, its advent responded to the need to make up for the tremendous amount of opaqueness involved in an individual's existence. The novel was invented to explore privacy - it offers detailed accounts of personal identities subsisting through duration - and since then, readers have attributed to it an unsurpassed capacity to reach and pierce the mysteries of life. ${ }^{8}$ And when humanity is invoked successfully once, the schema for this particular kind of invocation becomes widely available.

The novel, together with other interpretive frameworks, such as psychoanalysis, have promulgated life as a staged order of life events and consequently have created a hermeneutic context which demands a rationalization of our psychological impulses. This interpretive system, which applauds progress towards achievement as the main successful engagement in life-review, somehow downgrades the random quality of memory. A goal-oriented therapeutic framework presides selfknowledge nowadays (constantly practiced in the media) and, according to Rose (1997: 240), "[o]nly through being assembled together with an array of non-natural, non-individualized techniques which extend beyond the boundaries of the human skin is one capable of being a self with an autobiography". Studies in the sociology of storytelling (Craib 2000: 65-69; Roemer 1995: 181, 246-247) also point to the danger of the construction of narratives which make things natural, avoiding guilt. Craib calls them "bad-faith" narratives or no-choice stories, because one's agency does not have to be considered. They are "about what is done to me and what I am because these things have been done to me" (67). They carry a powerful anesthetic power in the form of standardized plots and they also legitimize an internal denial of the choices we make or the ones that are open for us.

Additionally, it is significant that feminist studies, which seek to counteract the dangerous effects of much of adult development theory, suggest the opposite direction: to forget sequences in order to get hold of sensations. ${ }^{9}$ An inescapable therapeutic ethos obliges us to be individuals of a certain sort. It is against the

8. Peter Brooks (1993: 28) suggests that it was the advent of the new concept of "private experience" or "private life" that created the need for the novel.

9. See Fisher (1989) and García (1989). These critics propose that agency can indeed be achieved when not seeking to attain any particular goal. 
difficulty to understand oneself outside this discourse that Daisy rebels, finding in the potentiality of the short story a more authentic approach to selfhood.

The general purpose of this essay has been to draw attention to the fact that the generic frame has to be taken into account for a better understanding of the ever-present activity of self-scrutiny. Genre is not only about how we read certain elements in a given text and it does not only generate literary activity. Genre helps to regulate the perceptions of ourselves. It is performative, not substantive, it infiltrates into alien structures, as the short story mode did in this novel.

\section{REFERENCES}

Alverson, Hoyt. 1994. Semantics and Experience: Universal Metaphors of Time in English, Mandarin, Hindi, and Sesotho. Baltimore: The Johns Hopkins University Press.

Bakhtin, Mikhail. 1991 (1975). Teoría y Estética de la Novela. Madrid: Taurus Humanidades. Trans. Helena S. Kriúkoba y Vicente Cazcarra.

Balza, José. 1995. "El Cuento: Lince y Topo." Teorías del Cuento I. Ed. Lauro Zabala. México: Universidad Nacional Autónoma de México. 61-65.

Bachelard, Gaston. 1969. The Poetics of Space. Boston: Beacon Press. Trans. Maria Jolas.

Barthes, Roland. 1988 (1953). "Writing and the Novel." Writing Degree Zero. Essentials of the Theory of Fiction. Eds. Michael Hoffman and Patrick Murphy. New York: Duke University Press. 144-151. Trans. Annette Lavers and Colin Smith.

Bawarshi, Anis. 2003. Genre and the Invention of the Writer: Reconsidering the Place of Invention in Composition. Logan: Utah State University Press.

Bayley, John. 1988. The Short Story: Henry James to Elizabeth Bowen. Brighton: The Harvester Press.

Borges, Jorge Luis. 1967. "Página para Recordar al Coronel Suárez, Vencedor en Junín." Obra Poética. Buenos Aires: Emecé.

Bowen, Elizabeth. 1994 (1937). "The Faber Book of Modern Short Stories." The New Short Story Theories. Ed. Charles E. May. Athens: Ohio University Press. 256-262. Brooks, Peter. 1993. Body Work: Objects of Desire in Modern Narrative. Cambridge: Harvard University Press.

Cortázar, Julio. 1973. "Del cuento breve y sus alrededores." La casilla de los Morelli. Barcelona: Tusquets. 
NARRATIVE GENRES AND THE ADMINISTRATION OF CONSCIOUSNESS: THE CASE OF DAISY..

Craib, Ian. 2000. "Narratives As Bad Faith." The Uses of Narrative: Explorations in Sociology, Psychology, and Cultural Studies. Eds. Molly Andrews et al. New Brunswick and London: Transaction Publishers. 64-74.

Dickinson, Emily. 1987. The Complete Poems. Ed. Thomas H. Johnson. London and Boston: Faber and Faber.

Fernández Prieto, Celia. 1994. "La verdad de la autobiografía." Revista de Occidente, 154: 116-130.

Fisher, Jerilyn. 1989. "Teaching “Time”: Women's Responses to Adult Development." Taking Our Time: Feminist Perspectives on Temporality. Eds. Frieda Johles Forman with Caoran Sowton. Oxford: Pergamon Press. 136-149.

Forster, Dennis A. 1987. Confession and Complicity in Narrative. Cambridge: Cambridge University Press.

García, Irma. 1989. "Femalear Explorations: Temporality in Women's Writing." Taking Our Time: Feminist Perspectives on Temporality. Eds. Frieda Johles Forman with Caoran Sowton. Trans. Eva G. Reisman. 161-182.

Giddens, Anthony. 1991. Modernity and Self-Identity. Self and Society in the Late Modern Age. Cambridge: Polity Press.

Gilmore, Leigh. 2001. The Limits of Autobiography: Trauma and Testimony. Ithaca: Cornell University Press.

Hallet, Cynthia J. 1996. "Minimalism and the Short Story." Studies in Short Fiction 33 (4): 487-495.

Hannah, Barry. 1998. "Speaking of Writing: 'Spies with Music'." The Tales We Tell: Perspectives on the Short Story. Eds. Barbara Lounsberry et al. London: Greenwood Press. 207-211.

Hanson, Clare. 1989. “'Things out of Words:' Towards a Poetics of Short Fiction." Re-reading the Short Story. Ed. Clare Hanson. London: MacMillan. 22-33.

Hillis Miller, J. 1979. The Form of Victorian Fiction. Cleveland, Ohio: Arete Press.

Kermode, Frank. 1968 (1966). The Sense of an Ending: Studies in the Theory of Fiction. Oxford: Oxford University Press.

Kosinski, Jerzy. 1978 (1972). "Jerzy Kosinski Interviewed by Jerome Klinkowitz." The New Fiction. Interviews with Innovative American Writers. Ed. Joe David Bellamy. Chicago: University of Illinois Press. 142-168.

Kroetsch, Robert. 2001. The Hornbooks of Rita K. Edmonton: Alberta University Press.

Leitch, Thomas M. 1989. "The Debunking Rhythm of the American Short Story." Short Story Theory at a Crossroads. Eds. Susan Lohafer and Jo Ellyn Clarey. Baton Rouge \& London: Louisiana State University Press. 130-147. 
Lohafer, Susan. 1998. "Interdisciplinary Thoughts on Cognitive Science and Short Fiction Studies." The Tales We Tell: Perspectives on the Short Story. Eds. Barbara Lounsberry et al. 147-150.

May, Charles E. 1993. "Reality in the Modern Short Story." Style. The Short Story: Theory and Practice 27 (3) Fall: 369-385.

May, Charles E. 1994. "The Nature of Knowledge in Short Fiction." The New Short Story Theories. Ed. Charles May. Athens: Ohio University Press. 131-143.

Musil, Robert. 1995 (1952). The Man Without Qualities. London: Picador. Trans. Sophie Wilkins.

Raible, Wolfgang. 1988. "Qué son los géneros: Una respuesta desde el punto de vista semiótico y de la lingüística textual." Teoría de los géneros literarios. Ed. Miguel Garrido Gallardo. Trans. Kurt Spang. Madrid: ARCO/LIBROS. 303-339.

Roemer, Michael. 1995. Telling Stories: Postmodernism and the Invalidation of Traditional Narrative. London: Rowman \& Littlefield Publishers.

Rohrberger, Mary. 1998. "Where Do We Go from Here? The Future of the Short Story." The Tales We Tell: Perspectives on the Short Story. Eds. Barbara Lounsberry et al. 201-205.

Rose, Nikolas. 1997. "Assembling the Modern Self." Rewriting the Self: Histories from the Renaissance to the Present. Ed. Roy Porter. London \& New York: Routledge. 224-248.

Rueda, Ana. 1992. Relatos desde el vacío. Madrid: Orígenes.

Taylor, Charles. 1996 (1989). Sources of the Self. The Making of Modern Identity. Cambridge: Cambridge University Press.

Serrano, Javier. 1995. "Discurso narrativo y construcción autobiográfica." Revista de psicología social aplicada. 5 (1/2): 41-56.

Shields, Carol. 1995 (1993). The Stone Diaries. New York: Penguin.

Trussler, Michael. 1996. "Suspended Narratives: The Short Story and Temporality." Studies in Short Fiction 33 (4): 557-577.

Wolff, Tobias. 2000. "Foreword." On Writing Short Stories. Ed. Tom Bailey. New York \& Oxford: Oxford University Press. xi-xii. 